\title{
A New Type of Synthesis of 1,2,3- Thiadiazole and 1,2,3-Diazaphosphole Derivatives Via-Hurd-Mori Cyclization
}

\author{
MONA A. HOSNY*, TAGHREED H. EL-SAYED, EMTITHAL A. EL-SAWI \\ Department of Chemistry, Faculty of Women for Arts, Science and Education, Ain \\ Shams University, Cairo, Egypt. \\ monaaminhosny@yahoo.com
}

Received 13 November 2011; Accepted 15 January 2012

\begin{abstract}
We present a short and efficient synthesis of the title compounds starting with cheap and readily available camphor and derivatives of acetophenone. The optimized sequence allows the large-scale preparation of this new type of synthesis in a few steps. New 1, 2,3-thiadiazole and 1,2,3diazaphosphole derivatives 11-20, were prepared from the ketones 1-5 via the corresponding semicarbazones 6-10. The Hurd-Mori and Lalezari methods were used, respectively, for the preparation of these 1,2,3-thiadiazole and 1,2,3-diazaphosphole derivatives. These derivatives exhibit anticancer effect due to their high potential biological activity.
\end{abstract}

Keywords: Semicarbazone, 1,2,3-diazaphosphole, 1,2,3-thiadiazole.

\section{Introduction}

Derivatives of 1,2,3-thiadiazoles and 1,2,3-diazaphosphole are known to exhibit antiinflammatory ${ }^{1-3}$, antiviral ${ }^{4,5}$, analgesic ${ }^{6,7}$, antimicrobial ${ }^{8-12}$, anticonvulsant ${ }^{13-16}$ and antidepressant activity. ${ }^{17}$ Among the pharmacological profiles of 1,2,3-thiadiazoles and 1,2,3-diazaphospholes, their antimicrobial, anticonvulsant and antidepressant properties seem to be the best documented. 1,2,3-thiadiazoles and related compounds are of great interest in chemistry owing to their bioactivity of certain plant growth regulating effect as well as antimicrobial activity. ${ }^{18,19}$ In spite of the obvious attraction of P and Sheterocycles, only a few preparative routes have been described. Antitubercular activities of thiadiazoles linked with aromatic cycles through the methyleneoxy group have also been reported and compounds of this type have shown inhibition on both cycloxygenase and 5-lipoxygenase activities. ${ }^{2,20}$ Lee and coworkers have synthesized some thiadiazoles with antihelminthic activities. ${ }^{21}$ More recently, sulfonamide derivatives of 1,3,4-thiadiazoles have been reported to behave as a modulator of anticancer therapies in combination with some cytotoxic compounds. ${ }^{22-25}$ Lalezari et 
al. ${ }^{26-28}$ were the first to report the synthesis of 1,2,3-thiadiazole system, which had been prepared previously by Hurd and Mori. ${ }^{29}$ We report herein the synthesis of new compounds containing 1,2,3-thiadiazole and 1,2,3-diazaphosphole ring ${ }^{30,31}$ using the Lalezari et al. and Hurd and Mori methods. Some diazaphospholes demonstrated insecticidal, bactericidal, antiviral, antitumor and anticarcinogenic activity. ${ }^{32}$ As a part of our ongoing programme, aimed at searching for novel antibacterial and antiviral agents with high activity and low toxicity, a synthetic route has been developed to the title compounds.

\section{Experimental Section}

Melting points were taken on Gallen Kamp melting apparatus and were uncorrected. Thin layer chromatography was performed with fluorescent silica gel plates $\mathrm{HF}_{254}$ (Merck), and plates were viewed under $U_{254}$ and 265 light. Infrared spectra $\left(\lambda-\mathrm{cm}^{-1}\right)$ were recorded on Bruker Vector Germany and on Mattson FT-IR 1000, using $\mathrm{KBr}$ disks. Mass spectra are measured on GCQ Finnigan MAT. ${ }^{1} \mathrm{H}-\mathrm{NMR}$ spectra were recorded on Gemini-200 MHZ NMR spectrometer in DMSO- $\mathrm{d}_{6}$ spectra were internally referenced to TMS. Peaks are reported in ppm. Downfield of TMS. The antibacterial activity were determined in microanalytical center Cairo University and anticancer activity was done in National Cancer Institute, Cancer Biology Department, Pharmacology, Cairo University. D-(+)-camphor, di-methoxy acetophenone p-bromo acetophenone, p-nitro acetophenone p-amino acetophenone were obtained from Fluka or Aldrich.

General Procedure for the Preparation of Thiosemicarbazones $(6,7,8,9,10)$

A mixture of Camphor (1, 0.95 equivalent) or 3,4- dimethoxy acetophenone (2, 0.95 equivalent) or P-bromoacetophenone (3,0.95 equivalent) or p-nitro acetophenone (4, 0.95 equivalent) or $\mathrm{p}$-amino acetophenone $(\mathbf{5}, 0.95$ equivalent), respectively and thiosemicarbazide (1.00 equivalent) was dissolved in absolute ethanol $(30 \mathrm{ml})$. The mixture was heated for $5 \mathrm{hr}$. under reflux, then the solvent was removed under vacuum and the residue was washed with diethyl ether. A recrystallization from ethyl alcohol was carried out.

General Procedure for the Preparation of 1,2,3-thiadiazole $(11,12,13,14,15)$

An excess amount of thionyl chloride was stirred at room temperature and the thiosemicarbazones 6 or 7 or 8 or 9 or 10 were added in several portions. The mixtures were stirred at r.t. overnight until no more hydrogen chloride was produced, the product was washed with diethyl ether to give a good yields of the corresponding 1, 2, 3thiodiazoles as fine powders. A recrystallization from ethyl alcohol was carried out.

General procedure for the preparation of 1,2,3-diazaphosphole compounds $(16,17,18,19,20)$

Each of thiosemicarbazones 6 or 7 or 8 or 9 or $10(1 \mathrm{~mol})$ and triphenyl phosphine (1 mol) were dissolved in tetrahydrofuran $(10 \mathrm{ml})$ and the mixture was stirred at room temperature for 2 days. The product was washed with diethyl ether to give a good yields of the corresponding 1,2,3-diazaphospholes as five powders. A recrystallization from ethyl alcohol was carried out. 


\section{Results and Discussion}

In the present study, new 1,2,3-thiadiazole and 1,2,3-diazaphosphole derivatives were obtained started from a variety of ketones (1-5) containing $\alpha$-methylene group (scheme 1) that were first converted into their corresponding semicarbazones and then further converted into 1,2,3-thiadiazole by reaction of thiosemicarbazide with thionyl chloride $^{33-37}$ and into 1,2,3-diazaphosphole ring derivatives by triphenyl phosphine reductive ring closure of these thiosemicarbazide derivatives. ${ }^{30-32}$

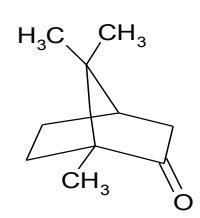

(1)

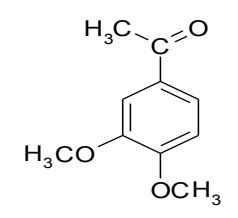

(2)<smiles>CC(=O)c1ccc(Br)cc1</smiles>

(3)<smiles>CC(=O)c1ccc([N+](=O)[O-])cc1</smiles>

(4)<smiles>CC(=O)c1ccc(N)cc1</smiles>

(5)

Scheme (1): Ketones used in the preparation of new 1,2,3-thiadiazole and 1,2,3diazaphosphole compounds

The general equations for the preparation of 1,2,3-thiadiazole and 1,2,3diazaphosphole derivatives are shown in scheme 2 .<smiles>[X][M]NN=C([R])C</smiles><smiles>[Y]C([Y])=S</smiles>

\section{Scheme (2)}


Table (1) shows the structures of the newly prepared compounds, melting point ranges and the percentage yields of these compounds.

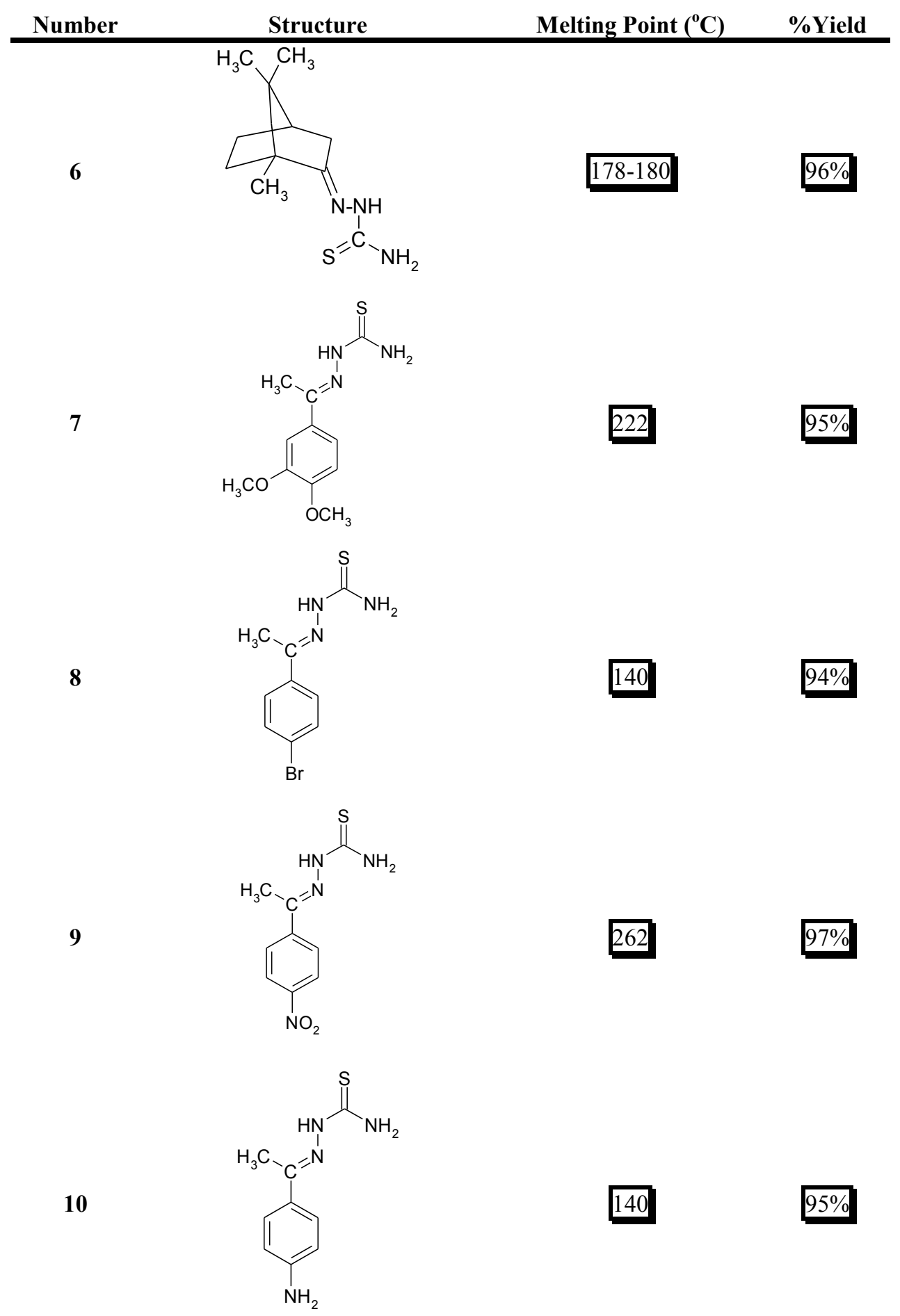


11<smiles>CC1(C)C2CCC1(C)C1SN(C(N)=S)N=C21</smiles>

Decompose at 266 60\%

12<smiles>COc1ccc(C2=NN(C(N)=S)SC2)cc1OC</smiles>

\section{6}

$72 \%$

13<smiles>O=S(=O)(Cl)NC1=NN=C(c2ccc(Br)cc2)C1</smiles>

Decompose at 240

14<smiles>O=[N+]([O-])c1ccc(C2=NN=C(NS(=O)(=O)Cl)C2)cc1</smiles><smiles>NC(=S)N1N=C(c2ccc(N)cc2)CS1</smiles> 
16<smiles>CC12CCC(C3=C1NN(C(N)=S)P3c1ccccc1)C2(C)C</smiles>

17<smiles>COc1ccc(C2=NN(C(N)=S)P(c3ccccc3)(c3ccccc3)(c3ccccc3)C2)cc1OC</smiles>

18<smiles>NC(=S)N1N=C(c2ccc(Br)cc2)CP1(c1ccccc1)(c1ccccc1)c1ccccc1</smiles>

19<smiles>NC(=S)N1N=C(c2ccc([N+](=O)[O-])cc2)C[PH]1(c1ccccc1)c1ccccc1</smiles>

20 
Compound (14) was of particular interest as it represents the unexpected compound in contrast the previous structures. Scheme 3 shows the proposed mechanism for the formation of compound (14). Its structure was confirmed by I.R, ${ }^{1} \mathrm{H}-$ NMR, mass spectrometry.

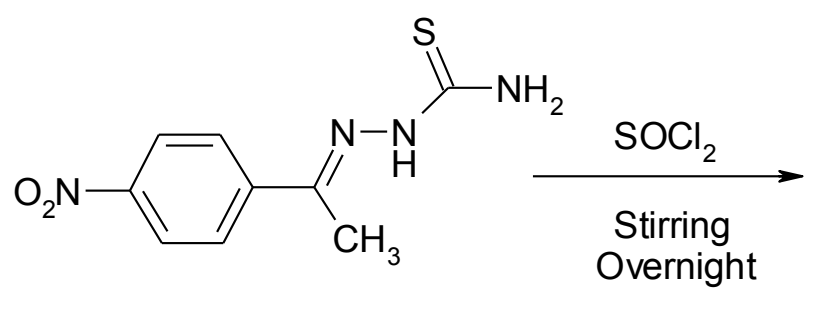

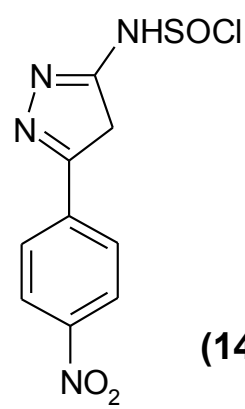

(14)

Scheme (3): Mechanism for the formation of compound (14).

Characterization data of newly compounds hydrazones (6-10) and 1,2,3thiadiazole (11-15) and 1,2,3-diazaphosphole (16-20).

Compound (6): White solid, IR (KBr) (cm-1): v:3369- 3264 (NH2), 3178 (NH), 2966 (CH3, str.), $1643(\mathrm{C}=\mathrm{N}), 1282(\mathrm{C}=\mathrm{S})$; MS (m/z \%): 225 (53, 43\%), 74 (100\%); ${ }^{1} \mathrm{HNMR}$, (DMSO-d6) $\delta: ~ 0.7-0.95 ~(3 \mathrm{CH} 3), 1.24$ (CH2), 1.98 (CH2), 1.94 (CH2), 1.75 (CH), $2.07(\mathrm{NH} 2), 7.1(\mathrm{NH})$.

Compound (7): White solid, I.R (KBr) (cm-1): v: 3374-3266- (NH2), 3155 (NH), 1640 $(\mathrm{C}=\mathrm{N}), 1250(\mathrm{C}=\mathrm{S}) ; \mathrm{MS}(\mathrm{m} / \mathrm{z} \%): 253(100 \%) ;{ }^{1} \mathrm{H}-\mathrm{NMR}$, (DMSO-d6) $8: 3.78-3.82(2$ OCH3), $1.18(\mathrm{SH}), 2.52$ (NH2 tauto.), 2.27 (CH3), 6.91-8.22 (Ar. protons), $9.75(\mathrm{NH})$.

Compound (8): Brown solid, I.R. (KBr) (cm-1): v: 3446-3330 (NH2), 3154 (NH), $1671(\mathrm{C}=\mathrm{N}), 1268(\mathrm{C}=\mathrm{S})$; MS (m/z \%): 272 (8.91\%), $256(100 \%)$; ${ }^{1} \mathrm{H}-\mathrm{NMR}$, (DMSOd6). $\delta: 1.21(\mathrm{SH}), 8.29$ (NH2 tauto.), $2.27(\mathrm{CH} 3), 6.86-7.98$ (Ar. protons), $10.24(\mathrm{NH})$.

Compound (9): Yellow solid, IR (KBr) (cm-1): v:3478-3355 (NH2), 3197 (NH), 1585. $(\mathrm{C}=\mathrm{N}), 1247(\mathrm{C}=\mathrm{S})$; MS (m/z \%): 238 (14.34\%), 223 (100\%); ${ }^{1} \mathrm{H}-\mathrm{NMR}$, (DMSO-d6). $\delta: 1.05(\mathrm{SH}), 2.35(\mathrm{CH} 3), 7.48-8.20$ (Ar. Protons), $8.45(\mathrm{NH} 2), 10.36(\mathrm{NH})$.

Compound (10): Brown solid, IR (KBr) (cm-1): v:3392 - 3249 (NH2), 3154 (NH), $1660(\mathrm{C}=\mathrm{N}), 1284(\mathrm{C}=\mathrm{S})$; MS (m/z \%): 208 (24.60\%), 59 (100\%); ${ }^{1} \mathrm{H}-\mathrm{NMR}$, (DMSOd6). $\delta: 2.38(\mathrm{NH} 2), 2.26(\mathrm{CH} 3), 6.62-7.93$ (Ar. protons), 8.23 (Ar. NH2), 10.18 (Ar. protons).

Compound (11): Pale orange, I.R (KBr) $(\mathrm{cm}-1)$ : v: 3046-3138 $\left(\mathrm{NH}^{+}\right), 1618(\mathrm{C}=\mathrm{N})$, $1268(\mathrm{C}=\mathrm{S}), 1402(\mathrm{C}-\mathrm{S})$; MS (m/z\%): 293 (1.44\%), 64 (100\%); ${ }^{1} \mathrm{H}-\mathrm{NMR}$, (DMSO-d6). $\delta: 1.23(\mathrm{CH}), 1.05(\mathrm{SH}), 4.13(\mathrm{NH}), 7.5$ 3-7.23 (Ar. protons). 
Compound (12): Yellow solid, IR (KBr) (cm-1): v: 3390 -3129 (NH2), 1591 (C=C), 1404 (C-S), $1268(\mathrm{C}=\mathrm{S})$; MS (m/z \%): $283(22.80 \%), 165$ (100\%); ${ }^{1} \mathrm{H}-\mathrm{NMR}$, (DMSO-d6) $\delta: 1.3$ (CH3), 3.8 (2OCH3), 4.64 (NH2), 7.12-7.62 (Ar. protons).

Compound (13): Brown solid, IR (KBr) (cm-1): v: 3135 (NH), 2815(CH2 aliphatic), 1683 $(\mathrm{C}=\mathrm{N}), ; \mathrm{MS}(\mathrm{m} / \mathrm{z} \%): 323$ (23.80\%), 64 (100\%); ${ }^{1} \mathrm{H}-\mathrm{NMR},(\mathrm{DMSO}-\mathrm{d} 6)$ ) $8: 4.62$.

$(\mathrm{NH}), 5.48(\mathrm{CH}), 11.64(\mathrm{NH})$, 7.19-7.7 (Ar. protons).

Compound (14): Bage solid, IR (KBr) (cm-1): v: 3165 (NH), 3040 (Ar. C-H), 2840 (CH2 aliphatic), $1590(\mathrm{C}=\mathrm{N}), \mathrm{MS}$ (m/z\%): 287 (10.4\%), 60 (100\%); ${ }^{1} \mathrm{H}-\mathrm{NMR}$, (DMSOd6). $\delta: 2.35(\mathrm{CH} 2) 83.89(\mathrm{NH}), 8.02-8.44$ (Ar. protons).

Compound (15): Yellow solid, IR (KBr) (cm-1): v:3480- 3320 (NH2), ,3129 NH,3041 (Ar. C-H),. $2805(\mathrm{CH} 2$ - aliphatic), $1627(\mathrm{C}=\mathrm{N}), 1600(\mathrm{Ar}-\mathrm{C}=\mathrm{C}), 1226(\mathrm{C}=\mathrm{S})$; MS. (m/z \%): 238 (19.97\%), 64 (100\%); ${ }^{1} \mathrm{H}-\mathrm{NMR}$, (DMSO-d6) 81.13 (CH2), 4.52 (NH2), 6.73 (NH2-Ar), 7.1-7.61 (Ar. protons).

Compound (16): White solid, IR (KBr) (cm-1): v: 3450 -3399 (NH2), $3064(\mathrm{NH})$, $1654(\mathrm{C}=\mathrm{C}), 1473$ (-P-Ph), $1268(\mathrm{C}=\mathrm{S}), 1089$ (C-P ); MS (m/z \%): 485 (0.03\%), 183 (100\%); ${ }^{1} \mathrm{H}-\mathrm{NMR}$, (DMSO-d6) $\delta: 1.06$ (3CH3), 4.36 (NH2), 7.25-7.48 (Ar. protons), $7.58(\mathrm{NH})$.

Compound (17): Pale Bage solid, IR (KBr) (cm-1): v:3372-3264 (NH2), 2992-2840 (CH2 Aliphatic), $1641(\mathrm{C}=\mathrm{N}), 1604$ (Ar. C=C), $1438(\mathrm{PPh}), 1253(\mathrm{C}=\mathrm{S}), 1081$ (C-P ), MS (m/z\%) 482 (0.06\%), 277 (100\%); ${ }^{1} \mathrm{H}-\mathrm{NMR}$, (DMSO-d6) $\delta: 1.8(\mathrm{CH}), 2.27$ (NH2), 3.78, 3.82 (2OCH3), 6.91-8.22 (Ar. protons), $\delta 10.07(\mathrm{NH})$.

Compound (18): Brown solid, IR (KBr) (cm-1): v: 3434-3360 (NH2), 3035 (CH-Ar.), $2880(\mathrm{CH} 2$ - aliphatic), $1600(\mathrm{ArC}=\mathrm{C}), 1577(\mathrm{C}=\mathrm{N}), 1481(\mathrm{P}-\mathrm{Ph}), 1286(\mathrm{C}=\mathrm{S}), 1083$. (C-P); MS (m/z \%): 532 (3.98\%), 60 (100\%); ${ }^{1} \mathrm{H}-\mathrm{NMR},(\mathrm{DMSO}-\mathrm{d} 6)$ ) $2.27(\mathrm{CH}), 6.82-$ 7.88 (Ar. protons), 8.2 (NH-C-SH).

Compound (19): Orange solid, IR (KBr) (cm-1): v: 3477-3354 (NH2), 3070 (Ar. C-H), 2968 (CH2 aliphatic). $1680(\mathrm{C}=\mathrm{N}), 1443(\mathrm{P}-\mathrm{Ph}), 1247(\mathrm{C}=\mathrm{S})$,

1078 (C-P); MS (m/z \%): 498 (0.33\%), 60 (100\%); ${ }^{1} \mathrm{H}-\mathrm{NMR}$, (DMSO-d6) $\delta$ :

$1.75(\mathrm{SH}), 2.35(\mathrm{NH}), 2.36(\mathrm{NH}), 4.48(\mathrm{CH}$-ethylene), 7.25-8.45 (Ar-protons).

Compound (20): Pale Bage solid, IR (KBr) (cm-1): v: 3390-3320 (NH2), 3041 (ArC-H), 2950 (CH2 aliphatic), $1595(\mathrm{C}=\mathrm{N}), 1480(\mathrm{P}-\mathrm{Ph}), 1267(\mathrm{C}=\mathrm{S}), 1116(\mathrm{C}-\mathrm{P})$, , MS (m/z \%): 468 (1.41\%), 277 (100\%); ${ }^{1} \mathrm{H}-\mathrm{NMR}$ (DMSO-d6) $\delta: 1.14(\mathrm{SH}), 2.22(\mathrm{NH}), 2.38$ $(\mathrm{NH}), 4.47$ (CH-ethylene), 6.83-8.16 (Ar. protons).

\section{Biological Activity}

Standard discs of Tetracycline (Antibacterial agent), amphotericin B (Antifungal agent) served as positive controls for antimicrobial activity but filter discs impregnated with $10 \mu \mathrm{l}$ of solvent (distilled water, chloroform, DMSO) were used as a negative control. 
The agar used is Meuller-Hinton agar that is rigorously tested for composition and $\mathrm{pH}$. Further the depth of the agar in the plate is a factor to be considered in the disc diffusion method. This method is well documented and standard zones of inhibition have been determined for susceptible and resistant values.

Blank paper disks (Schleicher and Schuell, Spain) with a diameter of $8.0 \mathrm{~mm}$ were impregnated $10 \mu$ of tested concentration of the stock solutions.

When a filter paper disc impregnated with a tested chemical is placed on agar the chemical will diffuse from the disc into the agar. This diffusion will place the chemical in the agar only around the disc. The solubility of the chemical and its molecular size will determine the size of the area of chemical infiltration around the disc. If an organism is placed on the agar it will not grow in the area around the disc if it is susceptible to the chemical. This area of no growth around the disc is known as a "Zone of inhibition" or "clear zone".

Table (2): Antifungal activity data and antibacterial activity.

\begin{tabular}{|c|c|c|c|c|c|}
\hline \multirow{2}{*}{\multicolumn{2}{|c|}{ Compound No. }} & \multicolumn{4}{|c|}{ Inhibition Zone Diameter ( $\mathrm{mm} / \mathrm{mg}$ sample) } \\
\hline & & Af & $\mathbf{C a}$ & Ec & Sa \\
\hline \multirow{2}{*}{ 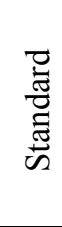 } & $\begin{array}{l}\text { Tetracycline } \\
\text { antibacterial } \\
\text { agent }\end{array}$ & - & - & 33 & 32 \\
\hline & $\begin{array}{l}\text { Amphotericin B } \\
\text { antifungal agent }\end{array}$ & 18 & 20 & - & - \\
\hline & 6 & 13 & 13 & 16 & 14 \\
\hline & 7 & 0.0 & 0.0 & 10 & 10 \\
\hline & 8 & 33 (US) & 11 & 12 & 11 \\
\hline & 9 & 0.0 & 0.0 & 10 & 10 \\
\hline & 10 & 0.0 & 0.0 & 12 & 11 \\
\hline & 11 & 12 & 12 & 13 & 13 \\
\hline & 12 & 12 & 12 & 14 & 13 \\
\hline & 13 & 13 & 11 & 13 & 14 \\
\hline & 14 & 0.0 & 0.0 & 10 & 11 \\
\hline & 15 & 0.0 & 0.0 & 14 & 15 \\
\hline & 16 & 14 & 13 & 13 & 12 \\
\hline & 17 & 0.0 & 0.0 & 10 & 10 \\
\hline & 18 & 36 (US) & 11 & 14 & 13 \\
\hline & 19 & 0.0 & 11 & 12 & 12 \\
\hline & 20 & 0.0 & 10 & 18 & 20 \\
\hline \multicolumn{6}{|c|}{$\begin{array}{l}\text { AF-Aspergillus flavus, Ca-Candida albicans, Ec- Escherichia coli, Sa - Staphylococcus } \\
\text { aureus } \\
\text { US: Unsporulated area. }\end{array}$} \\
\hline
\end{tabular}




\section{Antitumor Screening}

Chemotherapy is a major therapeutic approach for the treatment of both localized and metastasized cancers. In the present work newly compounds 1,2,3-thiadiazole and 1,2,3diazaphosphole were evaluated as inhibitors of the growth of breast cancer cell line in comparison to the known anticancer drug: Doxorubicin as a trial to get more effective and less toxic agent.

Preliminary experiments were done using the human tumor cell line to identify the potential toxicity of four chosen selected newly synthesized compounds $(11,12,16,17)$ (Fig. 1) in comparison to the known anticancer drug: doxorubicin by SRB using the method Skehan et al. ${ }^{38}$

- Cells were plated in 96-multiwell plate $\left(10^{4}\right.$ cells/well $)$ for $24 \mathrm{hrs}$ before treatment with compounds to allow attachment of cell to the wall of the plate.

- Different concentration of the compound under test $(0,1,2.5,5$ and $10 \mu \mathrm{g} / \mathrm{ml})$ were added to the cell monolayer triplicate wells prepared for each individual dose.

- Monolayer cells were incubated with the compounds for $48 \mathrm{hrs}$ at $37^{\circ} \mathrm{C}$ and atmosphere of $5 \% \mathrm{CO}_{2}$.

- After 48 hrs, cells were fixed, washed and stained with sulfo-rhodamine - $\beta$ stain.

- Excess stain was washed with acetic acid and attached stain was recovered with tris EDTA buffer.

- Color intensity was measured in an ELISA reader.

- The relation between surviving fraction and drug concentration is plotted to get the survival curve of each tumor cell line after the specified compound.

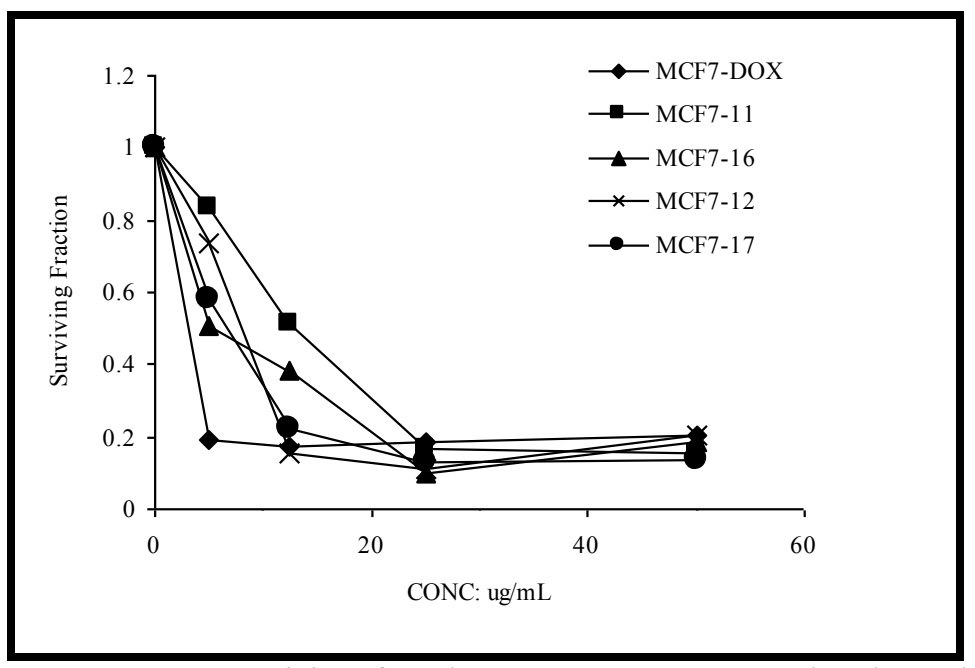

Figure (1): Drug cytotoxicity of product $11,16,12,17$ compared to doxorubicin. 
Table (3): Effect of some selected newly synthesized compounds on breast cancer cell line.

\begin{tabular}{lc}
\hline Compound & IC $_{\mathbf{5 0}}$ \\
\hline Doxorubicin & $3.13 \mu \mathrm{g} / \mathrm{ml}$ \\
\hline 11 & $12.8 \mu \mathrm{g} / \mathrm{ml}$ \\
16 & $5.4 \mu \mathrm{g} / \mathrm{ml}$ \\
12 & $8.1 \mu \mathrm{g} / \mathrm{ml}$ \\
17 & $6.79 \mu \mathrm{g} / \mathrm{ml}$ \\
\hline
\end{tabular}

$\mathbf{I C}_{\mathbf{5 0}}$ : Dose of the compound which reduces survival to $50 \%$.

\section{Conclusion}

In connection with our work on derivatives of acetophenone herein we describe a new type procedure for the synthesis of 1,2,3-thiadiazole and 1,2,3-diazaphosphole compounds via-Hurd Mori cyclization. The Hurd-Mori reaction is by far the most widely used method in the research on 1,2,3-thiadiazoles, and some reactions are carried out on an industrial scale. In view of these facts, the aim of the present study was to obtain 1,2,3-thiadiazole and 1,2,3-diazaphosphole derivatives where synthesized as antitumor agents. The antitumor activity results indicated that all the four derivatives showed antitumor activity against the tested breast cancer cell line but with varying intensities in comparison to the known anticancer drug: doxorubicin.

\section{References}

1. Unangst, P.C.; Shrum, G.P.; Dyer, D.T. and Schrier, D.J. J. Med. Chem. 1992; 35, 3691-98.

2. Mullican, M.D.; Wilson, M.W.; Connor, D.T.; Kostlan, C.R. and Schrier, D.J. J. Med. Chem. 1993; 36, 1090-99.

3. Boschelli, D.H.; Conner, D.T.; Bornemeir, D.A.; Dyer, R.D.; Kennedy, J.A.; Kuipers, P.J.; Okonkwo, G.C.; Schrier, D.J. and Wright, C.D. J. Med. Chem. 1993; 36, 1802-10.

4. Jones, D.H.; Slack, R.; Squires, S. and Wooldridge, K.H. J. Med. Chem. 1965; 8, 676-80.

5. Sidwell, R.W.; Robins, R.K. and Hillyard, I.W. Pharmacol. Ther. 1978; 6, 123-8.

6. Sughen, J.K. and Yologe, T. Pharm. Acta Helv. 1978; 58, 64-8.

7. Kelarev, V.I.; Karakhanov, R.A.; Gassanvo, S.Sh.; Morozova, G.V. and Kuatbekova, K.P.; J. Org. Chem. USSR 1993; 29, 323-9.

8. Shams El-Dine, Sh.A. and Hazza, A.A.B. Pharmazie 1974; 29, 761-8.

9. Misato, T.; Ko, K.; Honma, Y. and Taniyama, E. Jpn Kokai 1977; 77, 25028, Chem. Abstr. 1977; 87, 14705a.

10. Reisdorff, J.H.; Brandes, W.; Scheinpflug, H.; Homeyer, B. and Roessler, P.; Ger. Offen, 1977; 533-604, Chem. Abstr. 1978; 88, 13706b.

11. Van Reet, G.; Heeres, J. and Wals, L. US Patent 1979; 4, 160-838, Chem. Abstr. $1979 ; 91,175361 z$.

12. Habib, N.S.; Abdel-Hamid, S. and El-Hawash, M. Farmaco 1989; 44, 1225-32. 
13. Stillings M.R., Welbour A.P. and Walter D.S., J. Med. Chem. 1986; 29, 2280-84.

14. Kane, J.M.; Staeger, M.A.; Dalton, C.R.; Miller, F.P.; Dubley, M.W.; Ogden, A.M.L.; Kehne, J.H.; Ketteler, H.J.; McCloskey, T.C.; Senyah, Y.; Chimelewski, P.A. and Miller, J.A. J. Med. Chem. 1994; 37, 125-32.

15. Ainsworth, C.; Easton, N.R.; Livezey, M.; Morrison, D.E. and Gibson, W.R.; J. Am. Pharm. Assoc. 1962; 5, 383-9.

16. Chapleo, C.B.; Myers, M.; Myers, P.L.; Saville, J.F.; Smith, A.C.B.; Stillings, M.R.; Tuloch, I.F.; Walter, D.S. and Welbour, A.P. J. Med. Chem. 1986; 29, 227380 .

17. Kane, J.M.; Dubley, M.W.; Sorenson, S.M. and Miller, F.P. J. Med. Chem. 1988; 31, 1253-58.

18. Seaborg, G.T. Science 1984; 9, 223.

19. Sawhney, S.N.; Gupta, A. and Sharma, P.K. Indian J. Heterocycl. Chem. 1991; 1, 8.

20. Kramer, J.B.; Boschelli, D.H. and Connor, D.T. J. Heterocycl. Chem. 1994; 31, 1439.

21. Lee, B.H.; Dutton, F.E.; Clothier, M.F.; Bowman, J.W.; Davis, J.P.; Johnson, S.S.; Thomas, E.M.; Zantello, M.R.; Zinser, E.W.; McGuire, J.C.; Thompson, D.P. and Geary, T.G. Bioorg. Medic. Chem. Lett. 1999; 9, 1727.

22. Teicher, B.A.; Liu, S.D.; Liu, J.T. and Holden, S.A.; Herman, Anticancer Res. $1993 ; 13,149$.

23. Chegwidden, W.R. and Spencer, I.M. Inflammopharmaco 1995; 3, 231.

24. Parkkila, S.; Rajaniemi, H.; Parkkila, A.K.; Kivela, J.; Waheed, A.; Pastorekova, S.; Pastorek, J. and Sly, W.S. Proc. Natl Acad Sci USA, 2000; 97, 2220.

25. Supuran, C.T. and Scozzafava, A. Eur. J. Med. Chem. 2000; 35, 867.

26. Lalezari, I., Shafiee, A. Tetrahedron Lett 1969; 28, 5105.

27. Lalezari, I.; Shafiee, A. J. Org. Chem. 1971; 36, 2836.

28. Lalezari, I.; Shafiee, A.; Yalpani, M. J. Org. Chem. 1973; 38, 338.

29. Hurd, C.D.; Mori, R.I.; J. Am. Chem. Soc. 1955; 77, 5359.

30. Xiao-Qing, S.; Hong-Lei, L.; Hong-Yun, Z.; Hong-Quan, Z.; Hong-Yan, M.; QingAn, W.; Yu, Z.; Hong-Wei, H.; Chinese J. Struct. Chem. 2005; 24, 1211-1216.

31. Hua-Zhou, Y.; Mao-Tang, S.; Tao, L.; Yong-Zhou, H. Chinese J. Struct. Chem. 2008; 27, 1171-1174.

32. Hari Babu, Y.; Ani Kumar, M.; Srinivasulu, K.; Suresh Reddy, C. and Naga Raju, C. Arkivoc 2006; XV, 189-197.

33. Zimmer, O.; Meier H. J. Chem. Soc. Chem. Commun. 1982; 481.

34. Hanold, N.; Kalbitz, H.; Al-Samadi, M.; Meier, H.Z. Naturforsch. 1995; 50b, 1121.

35. Curran, W.V.; Sassiver, M.L.; Boothe, J.H.; Jacob, L.J. Heterocycle. Chem., 1985; 22,479 .

36. Katritzky, A.R. Physical Methods in Heterocyclic Chemistry; John Wiley and Sons, Inc., New York, 1963; 2, 234.

37. Fujita, M.; Kobori, T.; Hiyama, T.; Kondo, K. Heterocycles, 1993; 36, 33.

38. Skehan, P. and Storeng, R. J. Natl. Cancer Inst., 1990; 82, 1107-1112. 


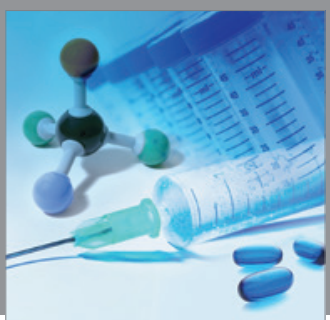

International Journal of

Medicinal Chemistry

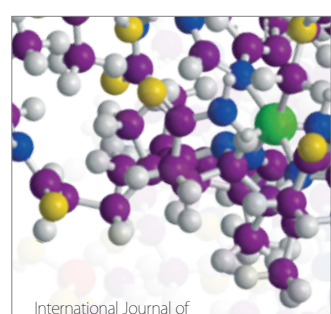

Carbohydrate Chemistry

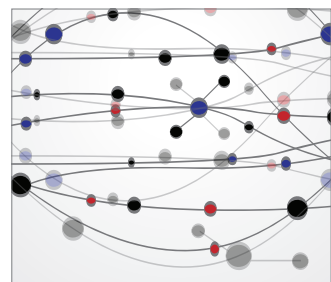

The Scientific World Journal
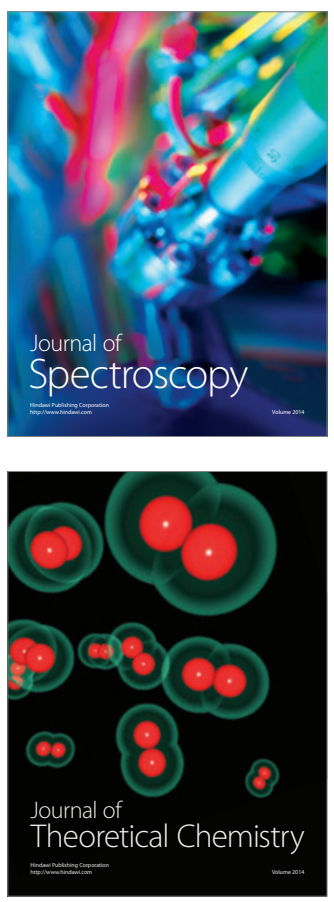
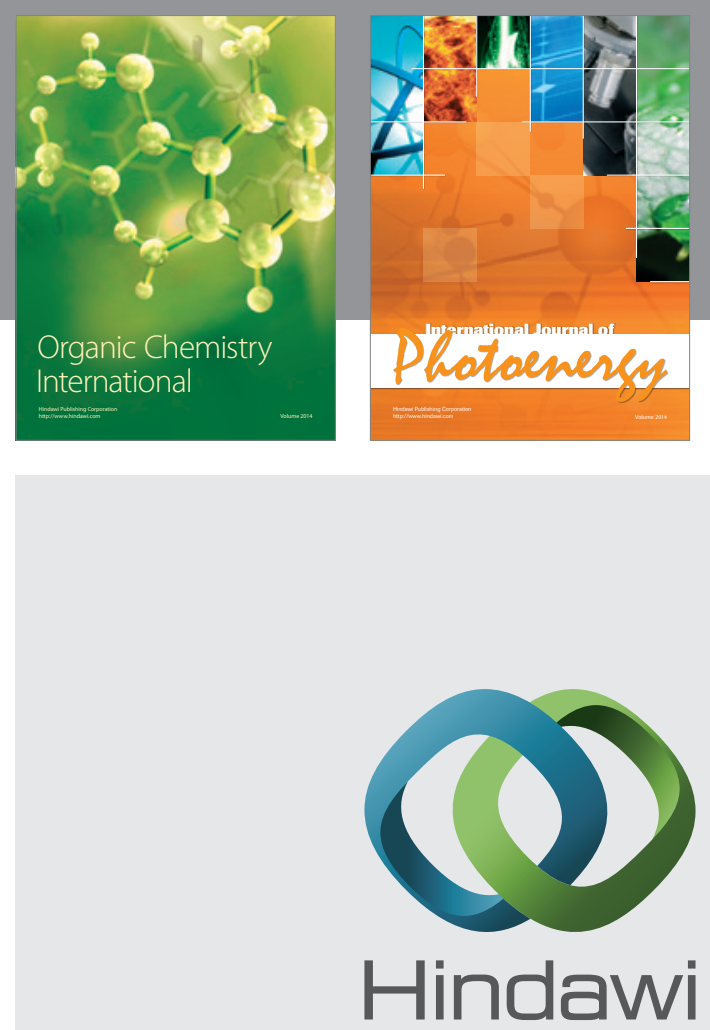

Submit your manuscripts at

http://www.hindawi.com
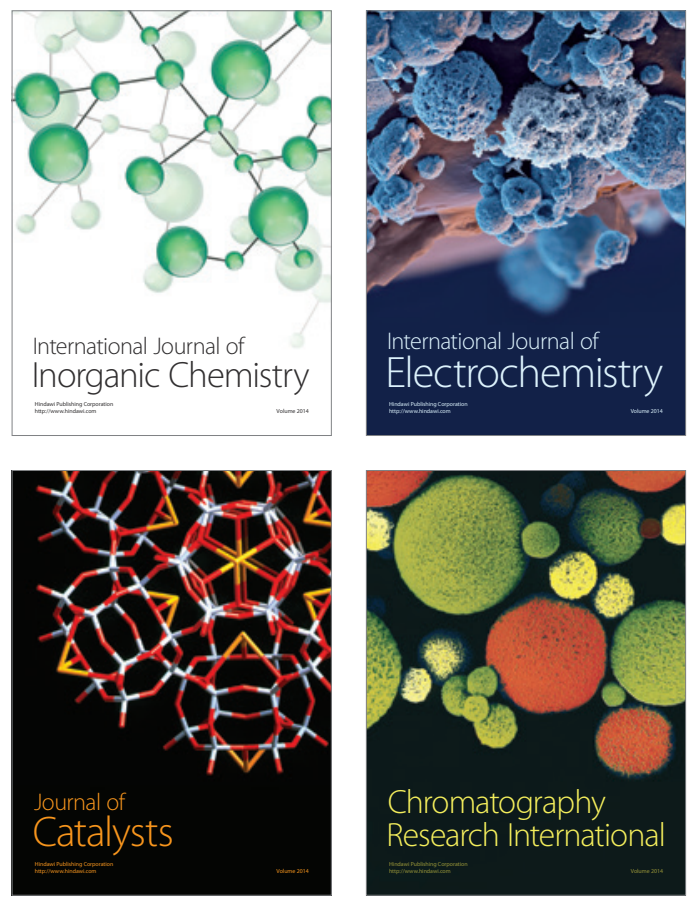
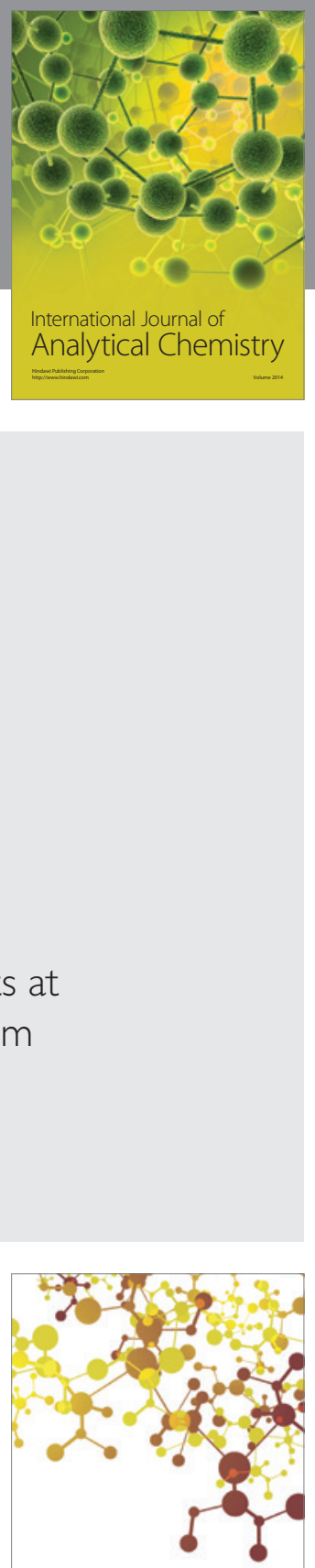

Journal of

Applied Chemistry
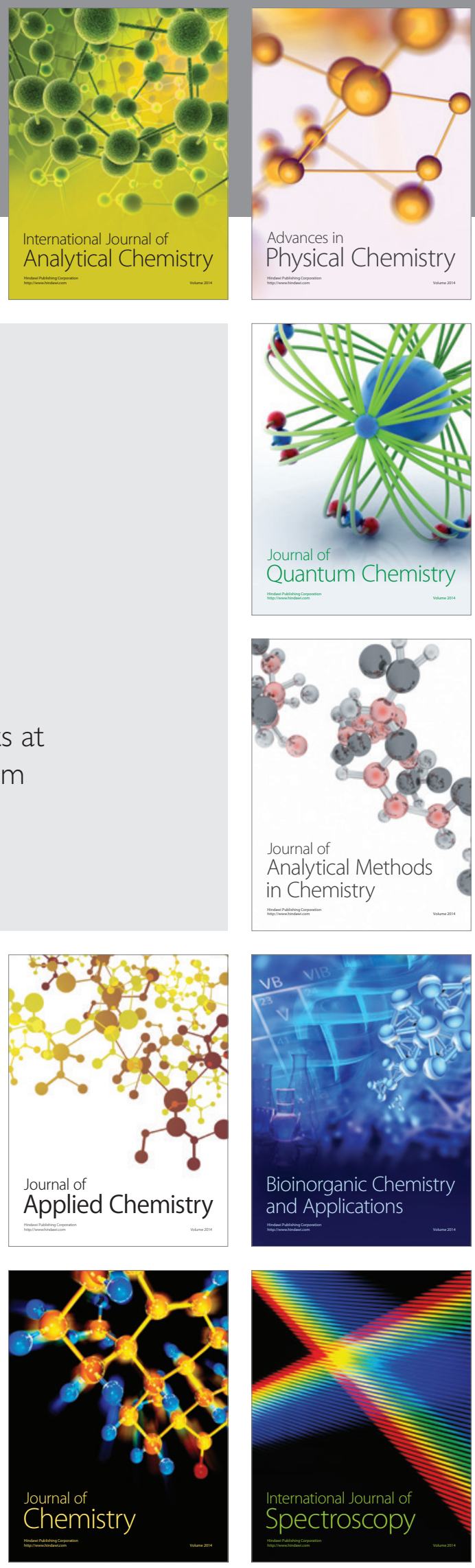